\title{
Urgentiniai neurosonologiniai tyrimai prie ligonio lovos COVID-19 pandemijos metu
}

\author{
J. Valaikienè \\ Vilniaus universiteto \\ Neurologijos centras
}

\begin{abstract}
Santrauka. Koronaviruso sukeltos ligos (COVID-2019) pandemija, išplitusi ir Lietuvoje, privertè imtis skubių saugumo priemonių, siekiant apriboti šios mirtinai pavojingos infekcijos plitimą visuomenèje ir gydymo ịstaigose. Straipsnyje pateikiama skubių ir neatidèliotinų neurologinių ultragarsinių tyrimų, atliekamų prie ligonio lovos, trumpiau tariant, neuroPOCUS (angl. point of care ultrasound), indikacijos, saugumo reikalavimai ir tyrimo technika bei klinikinio taikymo pavyzdžiai. Aptariami neuro-POCUS privalumai ir trūkumai.
\end{abstract}

Raktažodžiai: POCUS, ultragarsas, COVID-19 pandemija, skubi diagnostika, spalvinė duplekssonografija, insultas.

\section{IVADAS}

Staigus ir netikètas naujojo koronaviruso sukeltos ligos 2019 (angl. coronavirus infectious disease, COVID-19) protrūkis Kinijoje, sparčiai išplitęs ir $2020 \mathrm{~m}$. kovo $11 \mathrm{~d}$. pripažintas pandemija, tapo tikru iššūkiu tiek atskiroms šalims, tiek Pasaulio sveikatos apsaugos organizacijai (PSO) [1]. Dèl filogenetinio panašumo ị sunkaus ūminio respiracinio sindromo (angl. Severe Acute Respiratory Syndrome, SARS) virusą (80 \% identiškumas), naujasis koronavirusas buvo pavadintas SARS-CoV-2, kuris, vėlesniu tyrimų duomenimis, labiausiai panašus ị šikšnosparnių koronavirusus (96\% identiškumas) [2]. Eksponentiškai didejjant diagnozuotų COVID-19 atvejų skaičiui, teko skubiai kurti protokolus, užtikrinančius tiek pacientų, tiek jais besirūpinančių darbuotojų sveikatos apsaugą. Neuroradiologinių ir ultragarsinių tyrimų apsaugos protokolai virusinès infekcijos fone, didejjant kardiovaskulinių susirgimu skaičiui [3], igavo ypatingą svarbą. Tiek miokardo infarkto (MI), tiek galvos smegenų insulto (GSI) atveju visiems pacientams (su (be) COVID-19 patvirtinimu) būtina, negaištant laiko, atlikti ịprastini skubų ištyrimą ir gydymą, laikantis griežtų nuo COVID-19 apsaugos priemonių [4].

\author{
Adresas: \\ Jurgita Valaikiené \\ Vilniaus universiteto Neurologijos centras \\ Santariškiu g. 2, LT-08661 Vilnius \\ El.paštas jurgita.valaikiene@santa.lt
}

Siekiant suvaldyti COVID-19 infekcijos plitimą, ūmiu ir neatidèliotinų klinikinių būklių diagnostikoje ypatingą vertę igauna nauja ultragarsinių tyrimų kryptis - POCUS (angl. Point-Of-Care-Ultrasound), kurio pagrindinis privalumas - greitas neinvazinis tyrimo atlikimas prie ligonio lovos, padedantis gydytojui iš karto atsakyti ị konkretų klinikinị klausimą [5]. Lietuvoje iki šiol nebuvo skelbta apie skubaus neurosonologinių tyrimų atlikimo prie ligonio lovos, trumpiau - neuro-POCUS, įdiegimą į klinikinę praktiką. Straipsnyje apžvelgsime šio tyrimo istorinius aspektus, indikacijas, atlikimo techniką ir saugumo reikalavimus COVID-19 pandemijos metu, pateiksime klinikinio pritaikymo pavyzdžius.

\section{ULTRAGARSINIŲ TYRIMŲ RAIDA}

Neurosonologiniai tyrimai Vilniaus universiteto ligoninèje Santaros klinikose (VUL SK) atliekami nuo 1996 m. [6]. Be plačiai naudojamų pasaulyje ir Lietuvoje ekstrakranijinės spalvinès duplekssonografijos (EKSS) ir transkranijinès doplerografijos (TKD) tyrimų [7], 1997 m. ị klinikinę praktiką buvo ịdiegta transkranijinė spalvine duplekssonografija (TKSS) [8]. Sudetingais atvejais, esant neaiškiai diagnozei ir nestabiliai ligonio būklei, ultragarso aparatai būdavo vežami ị reanimacijos ir intensyviosios terapijos skyrius urgentiniams kaklo ir galvos kraujagyslių tyrimams atlikti prie ligonio lovos. $2017 \mathrm{~m}$. VUL SK patvirtinus transorbitalinès spalvinès sonografijos (TOSS) diag-

(C) Neurologijos seminarai, 2020. Open Access. This article is distributed under the terms of the Creative Commons Attribution 4.0 International License CC-BY 4.0 (http://creativecommons.org/licenses/by/4.0/), which permits unrestricted use, distribution, and reproduction in any medium, provided you give appropriate credit to the original author(s) and the source, provide a link to the Creative Commons license, and indicate if changes were made. 
nostikos protokolą, ultragarsiniai tyrimai pasipildè nauja metodika - akies kraujotakos ir regos nervo tyrimu [9, 10]. 2019 m. pavasari VUL SK atlikome pirmają kontrastinę EKSS ir TKSS, panaudodami kontrastinę medžiagą „SonoVue“, ir diagnozavome vidinės miego arterijos (VMA) disekacinio užsikimšimo vèlyvą dalinę rekanalizaciją, kuri buvo patvirtinta kompiuterinès tomografijos (KT) angiografija (neskelbti duomenys). Tais pačiais metais Vilniaus universiteto ligoninès Santaros klinikų Neurosonologijos laboratorija buvo pripažinta pirmuoju Lietuvoje referentiniu Europos neurosonologijos tinklo centru, atitinkančiu Europos neurologijos akademijos (angl. European Academy of Neurology, EAN) neurosonologijos mokslinio panelio ir Europos neurosonologijos ir cerebrinès hemodinamikos draugijos (angl. European Society of Neurosonology and Cerebral Hemodynamics, ESNCH) standartus.

\section{NEUROSONOLOGINIŲ TYRIMŲ INDIKACIJOS COVID-19 PANDEMIJOS METU}

\section{EKSS, TKSS:}

1) ūmus galvos smegenų išeminis insultas (GSI) ar praeinantis smegenų išemijos priepuolis (PSIP), ar staigus beskausmis apakimas, gręsiant GSI, kai lieka neaiški ịvykio etiologija po atliktos galvos smegenų KT su perfuzijos ir angiografijos režimu;

2) cervikocerebrinių arterijų disekacijos įtarimas, liekant neaiškiai diagnozei po GSKT su perfuzijos ir angiografijos režimu;

3) ruošiant ligoni neatidèliotinai širdies operacijai, esant daugybiniams kardiovaskuliniams rizikos veiksniams;

4) esant neaiškiai sąmonės sutrikimo/ epilepsinių priepuolių etiologijai po galvos smegenų KT, MRT ir EEG;

5) cerebriniam vazospazmui diagnozuoti po subarachnoidinès hemoragijos;

6) esant vaskulito įtarimui.

II. TOSS:

1) įtariant padidejjusị intrakranijinị spaudimą (IKS);

2) ịtariant tinklainès arterijos užsikimšimą ūmaus apakimo atveju;

3) ịtariant karotikokaverninę fistulę, liekant neaiškiai diagnozei po galvos smegenų KT angiografijos.

\section{KAIP SAUGIAI ATLIKTI \\ NEUROSONOLOGINIUS TYRIMUS COVID-19 ATVEJU?}

ESNCH ir EAN Neurosonologijos mokslinio panelio vadovaujančios grupès pateikè rekomendacijas neurosonologijos laboratorijoms COVID-19 pandemijos metu, kad būtų galima saugiai dirbti, apsaugant nuo užsikrẻtimo tiek pacientus, tiek ultragarsinị tyrimą atliekančius specialistus $[11,12]$. Nuorodos suderintos su PSO, Europos ligų pre- vencijos ir kontrolès centru (angl. European Center for Disease Prevention and Control) ir (ar) Ligu prevencijos ir kontrolès centru (angl. Center for Disease Control and Prevention, CDC) [13-16]. Atliekant neurosonologinius tyrimus, kiekviena šalis turètų laikytis nustatytų nacionalinių ir tarptautinių rekomendacijų.

Bendros rekomendacijos. Karantino metu turètų būti atliekami tik skubūs ir neatidèliotini ultragarsiniai tyrimai. Sprendimą, kokie tyrimai yra būtini ir (ar) neatidèliotini, priima konkrečios gydymo ịstaigos neurosonologinès laboratorijos specialistai, vadovaudamiesi patvirtintais ligoninės protokolais. Siekiant sumažinti COVID-19 infekcijos plitimą, vienbalsiai sutariama, kad nebūtinus planinius tyrimus reikia atidèti, ypač vyresniems ir didelès rizikos pacientams.

Rekomenduojama visus pacientus, kuriems numatomas ultragarsinis ištyrimas, prieš patenkant ị kabinetą patikrinti, atliekant standartizuotą testą su ūmios kvėpavimo takų infekcijos simptomų ir COVID-19 infekcijos rizikos veiksnių sąrašu (temperatūra, kosulys, krūtinės skausmas, dusulys, skonio, uoslès sutrikimas, galvos skausmai, mialgijos, vėmimas, diareja ir kt.). Kai kuriose šalyse kontrolès punktai yra ịrengti ịjjimo ị gydymo įstaigą vietoje.

I ultragarsinių tyrimų kabinetą rekomenduojama įleisti tiriamuosius be lydinčių asmenų, neatsižvelgiant ị tai, ar reikalinga pagalba dèl kalbos barjero ar mobilumo sutrikimo. Jeigu visgi to išvengti neịmanoma, lydintysis taip pat privalo būti patikrintas minètu standartizuotu testu. Siekiant sumažinti COVID-19 infekcijos plitimo riziką, svarbu užtikrinti, kad: 1) būtų laikomasi vizitui skirto laiko (rekomenduojama vizitui skirtą laiką prailginti, kad nesusidaryti eilių prie kabineto ir mažètų pacientų skaičius laukiamajame); 2) atstumas tarp kẻdžių būtų ne mažesnis negu 2 metrai; 3) ligoniai ir juos lydintieji dèvėtų veido kaukes ar respiratorius.

Pandemijos metu rekomenduojama neleisti kursantams ir studentams dalyvauti atliekant tyrimus.

Organizuojant darbą neurosonologinèse laboratorijose, rekomenduojama, esant galimybei, numatyti ultragarsinės komandos narius, kurie atliktų neurosonologinius tyrimus ūmaus insulto atveju, ir atskirą patalpą kontroliniams tyrimams atlikti.

Asmens apsaugos priemonès (AAP). Atlikdami ultragarsinius tyrimus COVID-19 pandemijos metu, medicinos darbuotojai privalo naudoti AAP pagal ligoninejje priimtus saugumo reikalavimus. Patvirtinto arba įtariamo COVID-19 atveju medicinos darbuotojai ị tyrimo patalpa privalo įeiti dėvėdami AAP: N95 ar FFP2 respiratorių, akinius arba veido skydeli, neperšlampamą chalatą ir ilgas vienkartines pirštines be latekso. Rekomenduojama, esant galimybei, tirti ligonị in situ arba „vietoje“, prie ligonio lovos, laikantis nurodytų daviklio ir aparato valymo bei dezinfekcijos taisyklių. İtariamais, galimais ar patvirtintais COVID-19 infekcijos atvejais, esant galimybei, rekomenduojama naudoti atskirą, tam skirtą ultragarso aparatą. Jeigu ligoni su nustatytu COVID-19 reikia tirti ultragarso laboratorijoje, patariama tyrimą atlikti sesijos pabaigoje, kadangi po to reikalinga kruopšti (generalinè) patalpos dez- 
infekcija. Sudėtingesnius diagnostinius atvejus rekomenduojama aptarti naudojant telemedicinines priemones. Tuo atveju, jeigu ultragarsu buvo tiriamas ligonis be visu rekomenduojamų AAP, neįtariant COVID-19 infekcijos, tačiau, ištyrus SARS-CoV-2, gautas teigiamas rezultatas, gydytojas ar sonoskopuotojas privalo apie tai skubiai pranešti infekcijos kontrolès skyriui ir izoliuotis.

Ultragarso aparatūros ir patalpos paruošimas dezinfekcijai. Po kiekvieno atlikto tyrimo ultragarsiniai davikliai, jų laidai ir aparatas turi būti dezinfekuojami specialiomis tam skirtomis priemonėmis pagal ligoninejje priimtą protokolą. Išoriniai davikliai, kuriais reikia tirti per užterštą ar pažeistą odą (pvz., esant odos infekcijai), turi būti izoliuoti vienkartinėmis daviklio ịmautėmis. Atkreipiamas dėmesys, kad prieš valant daviklị, jị reikia atjungti nuo skenerio. Rekomenduojama, kad pandemijos metu gelio, naudojamo ultragarsinio tyrimo metu, talpykla būtų vienkartiniame plastikiniame apsauginiame maišelyje, kurị būtų galima pakeisti po kiekvieno atlikto tyrimo.

Galiausiai, turi būti užtikrinta, kad ultragarso kabinetas būtų kruopščiai valomas ir dezinfekuojamas kiekvieną dieną, o visi kabinete esantys daiktai (UG monitorius, kompiuterio klaviatūra ir pelè, gelio talpykla, durų rankenos, kabineto rankenėlès, šviesų jungikliai, kèdès, kiti baldai ir aparatūra) turi būti valomi, naudojant tam skirtas specialias dezinfekcines priemones ir servetèles. Pasibaigus darbo dienai, nešvarūs skalbiniai, naudojant dvi poras pirštinių, atsargiai ir nekratant turi būti įdèti ị specialų tam skirtą konteinerị. Po to rankos 20 sekundžių plaunamos po tekančiu vandeniu ir dezinfekuojamos tinkamu dezinfektantu, kurio sudètyje yra ne mažiau nei $70 \%$ medicininio spirito.

\section{NEURO-POCUS TYRIMŲ YPATUMAI}

Visi skubūs ir neatidèliotini neurosonologiniai tyrimai, atliekami prie potencialaus COVID-19 ligonio lovos, turi būti atliekami kuo greičiau, todèl pandemijos metu rekomenduojama apsiriboti sutrumpintu tyrimo protokolu, išsaugant būtinus konkrečių kraujagyslių režimų (B režimo, spalvinio ir (ar) spektrinio doplerio) vaizdus žemiau nurodytose ultragarsinėse plokštumose, pažymėjus ultragarsinio tyrimo pusę (kairè ar dešinè). Baigus tyrimą, aparatas išjungiamas ir, pagal nurodytas gaires, išvalomas bei dezinfekuojamas. Matavimai ir papildomas vaizdų išsaugojimas bei tyrimų aprašymai atliekami vèliau saugioje neinfekuotoje patalpoje.

I. EKSS. Tyrimas atliekamas 7-15 MHz linijiniu davikliu. Siekiant sutrumpinti tyrimo laiką, patariama atlikti pagrindinių kaklo kraujagyslių - bendrosios miego arterijos (BMA), VMA, išorinès miego arterijos (IMA) ir slankstelinès arterijos (SA) V2 segmento išilginio pjūvio ir BMA bifurkacijos skersinio pjūvio tyrimą B režimu, spalviniu ir spektriniu režimais, išsaugant standartinius tyrimo vaizdus. Jeigu suformuluotas konkretus klausimas, pavyzdžiui, ar neužsikimšo kairès VMA stentas, tikslinga prie ligonio lovos atlikti tik kairès VMA tyrimą, išsaugant vaizdus B režimu, spalviniais ir spektriniais režimais (1 pav.).

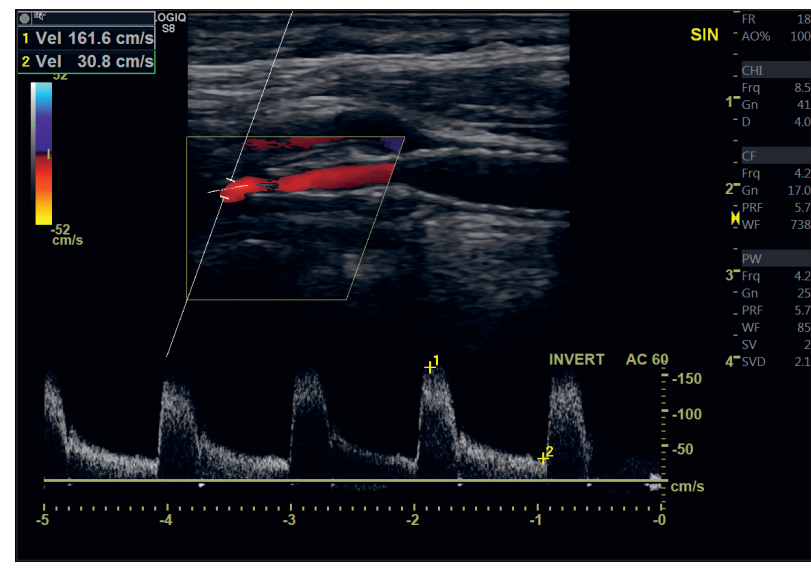

1 pav. Neuro-POCUS: ekstrakranijinė spalvinė duplekssonografija

Vidinė miego arterija (VMA), išilginè skenavimo plokštuma, spalvinio ir spektrinio doplerio režimas. VMA stento hiperechogeniniai artefaktai pažymėti rodyklëmis.

Klausimas: Ar ligonei su kairiosios VSA insultu funkcionuoja kairiosios VMA stentas?

Atsakymas: Taip, kairiosios VMA stentas funkcionuoja.

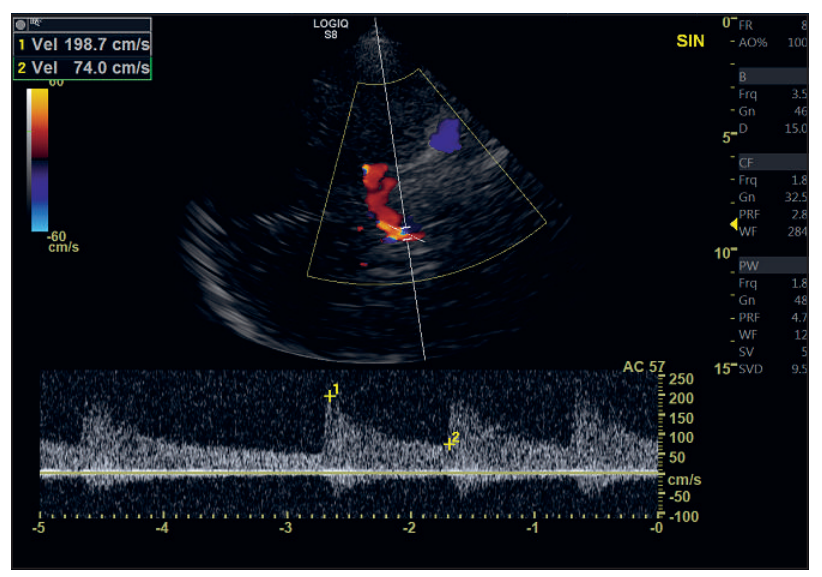

2 pav. Neuro-POCUS: transkranijinė spalvinė duplekssonografija.

Pamatinė arterija (PA), transtemporalinė apžiūra, koronarinė užpakalinė skenavimo plokštuma.

Klausimas: Ar ligoniui su vertebrobaziliniu insultu po selektyvios pamatinès arterijos trombolizès ir trombo aspiracijos liko PA stenozé?

Atsakymas: Taip, yra liekamoji PA stenozè $>50 \%$. Tyrimo metu registruotos dažnos ekstrasistolès. Rekomenduotas Holterio monitoravimas.

II. TKSS. Tyrimas atliekamas 1,75-3,5 MHz sektoriniu davikliu. Siekiant sutrumpinti tyrimo laiką, atliekama tikslinè apžiūra. Pavyzdžiui, esant vertebrobazilinei klinikai, atliekama standartinè transnuchalinė apžiūra, išsaugant SA V4 segmentų ir pamatinès arterijos (PA) vaizdus. Esant geram ultragarso pralaidumui (B režimu aiškiai matomas hipoechogeninis viduriniujuc smegenų pjūvis), transtemporalinės apžiūros koronariniame pjūvyje ịvertinama PA ir užpakalinė smegenų arterija (USA), P1/P2 segmentai, pažymėjus tyrimo pusę išsaugomi vaizdai, o vẻliau atliekami matavimai (2 pav.). Esant miego arterijos baseino patologijos klinikai, atliekama transtempo- 


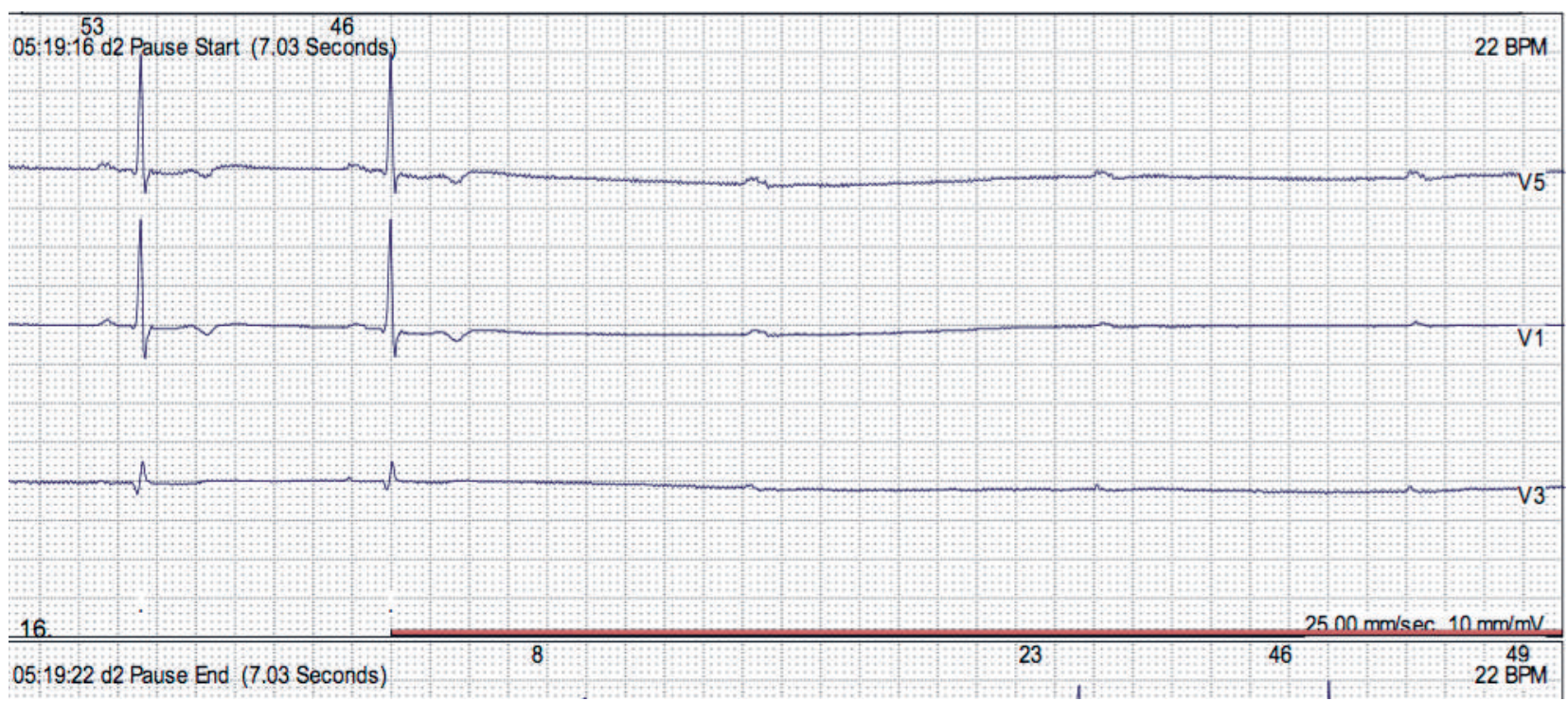

3 pav. Holterio monitoravimas: intermituojanti III laipsnio atrioventrikulinė blokada ir pauzès iki 7,1 sekundès

ralinė apžiūra, aksialiniame pjūvyje ịvertinant vidurinės smegenų arterijos (VSA) M1 segmento, priekinès smegenų arterijos A1 segmento ir VMA C1-2 segmento, o koronariniame pjūvyje - C4-5 segmento kraujotaką.

III. TOSS. İsitikinus, kad tiriamasis yra be linzių ir sumažinus mechaninị indeksą iki 0,23 (arba < 0,44, jeigu tai yra mažiausia aparato leidžiama vertè), 7-15 MHz linijinis daviklis dedamas ant užmerkto viršutinio akies voko. Išsivedama standartinė lateralinė horizontali skenavimo plokštuma, RN - hipoechogeninė struktūra, apsupta hiperechogeninio subarachnoidinio tarpo ir hipoechogeninio kietojo dangalo.
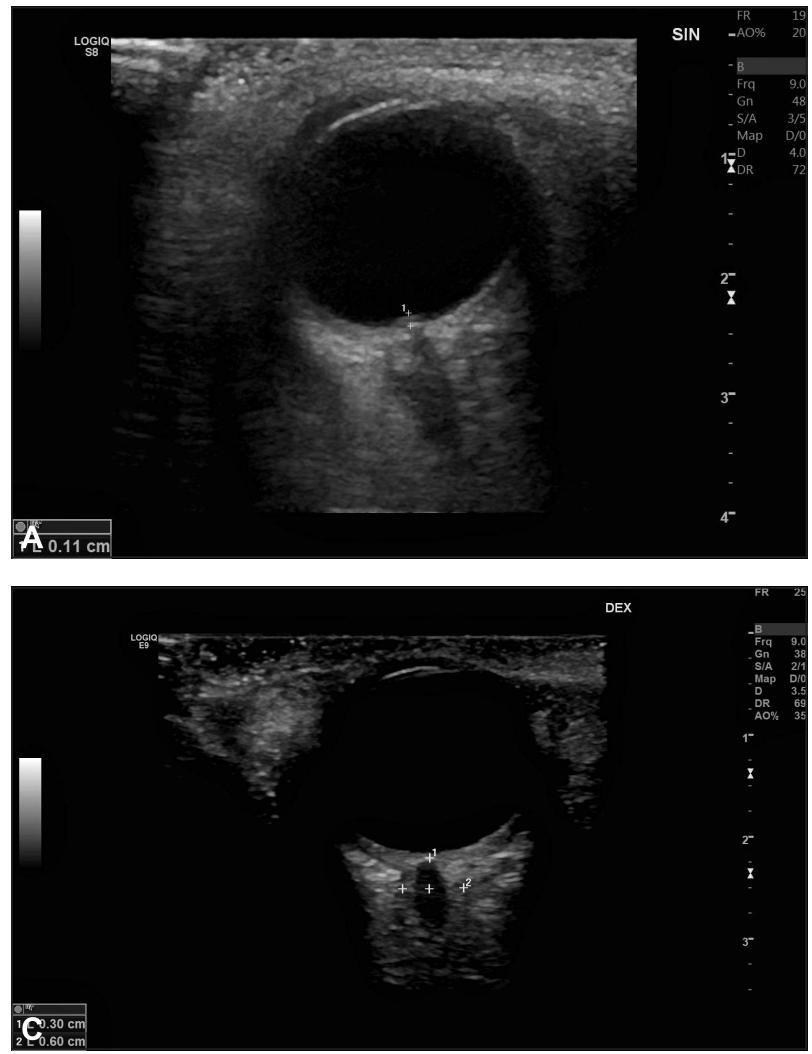

İtariant tinklainės arterijos užsikimšimą, atliekamas regos nervo (RN) galvutės tyrimas B režimu; nustačius hiperechogeninị taškinị požymị (angl. spot sign), išsaugomas vaizdas. Nenustačius taškinio požymio, ijungiamas spalvinis ir spektrinis režimai tinklainès arterijos ir venos greičiams registruoti, išsaugomas vaizdas, o matavimai atliekami vẻliau.

Esant padidejusio intrakranijinio spaudimo ịtarimui, $B$ režimu patikrinama, ar nėra paburkęs regos nervo diskas (4 pav., A) ir, išsivedus RN, išsaugomas vaizdas. RN dangalo diametro matavimai $3 \mathrm{~mm}$ už optinio disko atliekami vèliau (4 pav., B, C).

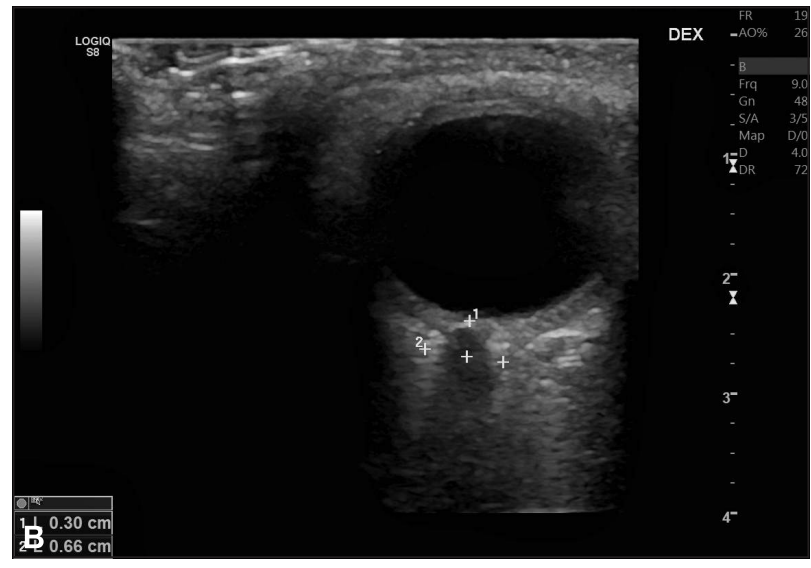

4 pav. Neuro-POCUS: transorbitalinė sonografija.

Klausimas: Ar ligonei su erkiniu encefalitu yra intrakranijinio spaudimo padidejjimo požymių?

Atsakymas: Taip, yra. Regos nervo (RN) disko paburkimas $1,1 \mathrm{~mm}$ (A), padidejęs RN dangalo diametras 6,6 mm (B). Po gydymo manitoliu: $\mathrm{RN}$ paburkimas atslūgo, $\mathrm{RN}$ dangalo diametras sumažèjo iki 6,0 mm (C). 


\section{APTARIMAS}

COVID-19 pandemijos metu taikant neuro-POCUS, laikantis saugumo reikalavimų, per trumpą laiką neinvaziniu būdu, nenaudojant radiacinès apšvitos, universaliu ultragarso aparatu gaunama vertinga informacija, kuri leidžia realiu laiku ịvertinti kaklo, galvos bei akies kraujotaką ir nustatyti padidèjusio intrakranijinio spaudimo požymius. Ultragarsinio tyrimo duomenys praverčia tikslinant diagnozę, ligos priežastị ir koreguojant ligonio tyrimų bei gydymo planą.

Retrospektyvaus Mao ir kt. tyrimo duomenimis, nustatyta, kad iš 214 Uhano miesto (Kinija) sergančiųju COVID-19 (vidutinis amžius - 52,7 m.; vyrų - 40,7 \%) su ūmiu kvėpavimo sutrikimo sindromu (angl. acute respiratory distress syndrom, ARDS) neurologiniai simptomai pasireiškẻ 36,6 \% tiriamųų. Sergamumas cerebrovaskulinemis ligomis buvo daug didesnis sergantiesiems sunkia COVID-19 pneumonija, nei sergantiems lengva ir vidutinio sunkumo pneumonija $(5,7 \%$ vs $0,8 \%)$ [17]. COVID-19 sergančius ligonius tiriant ultragarsu, nustatyta, kad POCUS pasižymi dideliu tikslumu, diagnozuojant pneumoniją [18]. Ūmių neurologinių susirgimų atveju, ypač didėjant insultų COVID-19 pandemijos metu, iškilo urgentinès neurosonologijos poreikis. İsigijus naujos portabilios aparatūros, tobulèjant atlikimo technikai, atsirado galimybè taikyti neuro-POCUS kasdieniame neurologo darbe. Pristatytos klinikinès situacijos demonstruoja klinikinę neuro-POCUS vertę: šiuo tyrimu galima realiu laiku registruoti kaklo ir galvos smegenų arterijų kraujotaką, identifikuoti ne tik stenozinius pakitimus, bet ir širdies veiklos sutrikimus. Ligoniui su vertebrobaziliniu insultu ir besikartojančiomis sinkopemis po atliktos PA trombo aspiracijos ir selektyvios trombolizès neuro-POCUS metu buvo nustatyta liekamoji PA stenozè ir ekstrasistolès (2 pav.). Prieš tai atliktose EKG ritmo sutrikimų nebuvo nustatyta. Tikslinant insulto ir sinkopių genezę, atliktas paros Holterio monitoravimas, kurio metu registruoti grèsmingi širdies ritmo sutrikimai ( 3 pav.), ir skubiai implantuotas dvikamerinis elektrokardiostimuliatorius. Ligonis išrašytas be parezių ir be ataksijos, sinkopès nesikartojo. Taigi, neuro-POCUS buvo diagnozuota ir urgentinè kardiologinè patologija. Pateikème TOSS taikymo pandemijos metu pavyzdị, demonstruodami šio tyrimo vertę encefalito su smegenų edema atveju. IKS padidẻjimo požymiai buvo nustatyti greituoju būdu tiesiog prie ligonio lovos, išvengiant galvos smegenų KT kartojimo su radiacine apšvita, ar kontaktinės okulisto apžiūros regos nervo disko edemai diagnozuoti.

Universalus POCUS tyrimas šiuo metu tiek Europoje, tiek visame pasaulyje ịgauna išskirtinę vertę. Jungtinėse Amerikos Valstijose POCUS tyrimas, taikomas tiek stacionare, tiek ir ambulatorineje grandyje, kaip skubi neinvazinè diagnostinè priemonè, diagnozuojant ne tik plaučių, griaučių, raumenų, pilvo organų ir kitas patologijas, ultragarso kontrolejje atliekant intervencines procedūras, pradètas integruoti ị medicinos mokyklų ir rezidentūros mokymo programas [19]. Visgi reikia pabrèžti, kad
POCUS tyrimo verte, greitis ir tikslumas priklauso ne tik nuo turimos aparatūros kokybès, bet ir nuo atliekančio gydytojo patyrimo bei igytos kompetencijos. COVID-19 pandemijos metu suspendavus mokymo procesą, ị tai reikia atsižvelgti [20].

Apibendrinant, neuro-POCUS, atliekamas patyrusio sonoskopuotojo ir laikantis saugumo instrukcijų, yra neinvazinis, tikslus ir greitas ultragarsinis tyrimas, tinkamas ir rekomenduojamas COVID-19 pandemijos metu ūmių neurologinių būklių diagnostikai prie ligonio lovos.

\section{IŠVADOS}

1. Atliekant neurosonologinius tyrimus, $\underset{i}{i}$ kiekvieną tiriamajji rekomenduojama žiūrèti kaip ì potencialy COVID-19 ligonį, naudojant AAP pagal priimtą algoritmą ir laikantis nustatytų ultragarso aparato priežiūros taisyklių.

2. Siekiant mažinti COVID-19 plitimą, pandemijos metu skubius ir neatidèliotinus neurosonologinius tyrimus rekomenduojama atlikti prie ligonio lovos arba kuo arčiau esančioje patalpoje, o planinius neurosonologinius tyrimus atidèti.

3. Siekiant sumažinti ekspozicijos su potencialiu COVID-19 ligoniu laiką, pandemijos metu siūloma atlikti neuro-POCUS, taikant sutrumpintą tyrimo protokolą, tiksliai atsakant ị konkretu klinikinị klausimą, sinchroniškai atliekant vaizdų ịrašymą, o tolimesnę analizę ir matavimus atlikti vèliau, ne prie ligonio lovos.

\section{Literatūra}

1. Mahajan A, Hirsch JA. Novel coronavirus: what neuroradiologists as citizens of the world need to know. AJNR Am J Neuroradiol 2020; 41(4): 552-4. https://doi.org/10.3174/ ajnr.A6526

2. Zhou P, Yang XL, Wang XG, et al. A pneumonia outbreak associated with a new coronavirus of probable bat origin. $\mathrm{Na}$ ture 2020; 579: 270-3. https://doi.org/10.1038/s41586020-2012-7

3. Li B, Yang J, Zhao F, Zhi L, Wang X, Liu L, et al. Prevalence and impact of cardiovascular metabolic diseases on COVID-19 in China. Clin Res Cardiol 2020; 109: 531-8. https://doi.org/10.1007/s00392-020-01626-9

4. Fraser JF, Arthur AS, Chen M, Levitt M, Mocco J, Albuquerque FC, et al. Society of NeuroInterventional Surgery recommendations for the care of emergent neurointerventional patients in the setting of covid-19. J Neurointerv Surg 2020; 12: 539-41. https://doi.org/10.1136/neurintsurg-2020016098

5. Moore S, Gardiner E. Point of care and intensive care lung ultrasound: a reference guide for practitioners during COVID-19. Radiography 2020; https://doi.org/10.1016/ j.radi.2020.04.005

6. Valaikienė J. Neurosonologija: spalvinė duplekssonografija. In: Ultragarsinè diagnostika - 2000. Metodinių rekomendacijų ir straipsnių rinkinys: Vilnius, 2000; 24-34. 
7. Jatužis D, Mameniškienė R, Tamošiūnas AE. Transkranijinė doplerografija neurologijoje ir neurochirurgijoje. Neurologijos seminarai 1998; 2(4): 36-45.

8. Valaikienè J, Tamošiūnas AE, Jatužis D, Budrys V, Parnarauskienė R. Suaugusiųų transkranijinè spalvinè duplekssonografija. Medicinos teorija ir praktika 1997; 3(11): 14-8.

9. Valaikienė J, Jatužis D. Transorbitalinès spalvinès sonografijos klinikinis pritaikymas neurologijoje. Neurologijos seminarai 2017; 21(71): 5-9.

10. Valaikienė J, Jatužis D. Kaklo ir galvos kraujagyslių ultragarsinès diagnostikos metodika. Metodinė mokymo priemonè (atnaujintas ir papildytas leidimas). Vilniaus universiteto leidykla, 2018.

11. ESNCH Guidance for neurosonology laboratories during COVID-19 pandemic. Available from: https://esnch.org/ esnch-guidance-for-neurosonology-laboratories-duringcovid-19-pandemic/

12. Management Group of the Scientific Panel on Neurosonology Recommendations during Covid-19 pandemic. Available from: https://www.eanpages.org/2020/04/09/ management-group-of-the-scientific-panel-onneurosonology-reccommendations-during-covid-19pandemic/

13. WFUMB Position Statement: How to perform a safe ultrasound examination and clean equipment in the context of COVID-19. Available from: https://www.journals.elsevier.com/ultrasoundin-medicine-and-biology/covid-19-special-collection/wfumbposition-statement-safe-ultrasound-covid-19

14. Centers for Disease Control. Interim infection prevention and control recommendations for patients with suspected or confirmed coronavirus disease 2019 (COVID-19) in healthcare settings. 2020. Available from: https://www.cdc.gov/coronavirus/2019-ncov/hcp/infectioncontrol-recommendations.html

15. Centers for Disease Control. Cleaning and Disinfection for Community Facilities. Interim Recommendations for U.S. Community Facilities with Suspected/Confirmed Coronavirus Disease 2019 (COVID-19). Available from: https://www.cdc.gov/coronavirus/2019-ncov/community/ organizations/cleaning-disinfection.html
16. US EPA. List N: Disinfectants for Use Against SARSCoV-2. Available from: https://www.epa.gov/pesticideregistration/list-n-disinfectants-use-against-sars-cov-2covid-19

17. Mao L, Jin H, Wang M, Hu Y, Chen S, He Q, et al. Neurologic manifestations of hospitalized patients with coronavirus disease 2019 in Wuhan, China. JAMA Neurol 2020; 77(6): 683-90. https://doi.org/10.1001/jamaneurol. 2020.1127

18. Buonsenso D, Piano A, Raffaelli F, Bonadia N, de Gaetano Donati K, Franceschi F. Point-of-care lung ultrasound findings in novel coronavirus disease-19 pnemoniae: a case report and potential applications during COVID-19 outbreak. Eur Rev Med Pharmacol Sci 2020; 24(5): 2776-80. https://doi.org/10.26355/eurrev_202003_20549

19. Arnold MJ, Jonas CE, Carter RE. Point-of-care ultrasonography. Am Fam Physician 2020; 101(5): 275-85.

20. Kim DJ, Jelic T, Woo MY, Heslop C, Olszynski P. Just the facts: recommendations on point-of-care ultrasound use and machine infection control during the coronavirus disease 2019 pandemic. CJEM 2020; 1-5. https://doi.org/10.1017/ cem. 2020.364

\section{J. Valaikienè}

\section{URGENT NEUROSONOLOGICAL EXAMINATIONS DURING COVID-19 PANDEMIC}

\section{Summary}

The pandemic of coronavirus disease 2019 forced to create urgent medical safety diagnostic protocols to limit the spread of this deadly infection. The article presents indications, safety requirements, techniques, and clinical examples of neurological pointof-care ultrasonography, or neuro-POCUS. The importance and limitations of the neuro-POCUS are discussed.

Keywords: POCUS, ultrasound, COVID-19 pandemic, urgent diagnostics, color duplex sonography, stroke.

Gauta:

Priimta spaudai:

20200505 20200607 